\title{
Effect of Grazing to Copper Pollution Meadow on Copper Metabolism in Wumeng Semi-fine Wool Sheep
}

\author{
Yongkuan Chi ${ }^{1,2}$, Kangning Xiong1,2, Hu Chen ${ }^{1,2}$, Xiaoying Min ${ }^{1,2}$, Hua Xiao ${ }^{1,2}$, \\ Jianjun Liao', Xiaoyun Shen ${ }^{1 *}$
}

${ }^{1}$ School of Karst Science, Guizhou Normal University, Guiyang, Guizhou, P.R. China

${ }^{2}$ State Engineering Technology Institute for Karst Desertfication Control, Guizhou Normal University, Guiyang, Guizhou, P.R. China

Received: 14 January 2018

Accepted: 20 March 2018

\begin{abstract}
To assess the effect of copper pollution meadow on grazing Wumeng semi-fine wool sheep and find an action plan to solve copper pollution, two experiments (grazing and sulfur supplementation) were conducted on copper pollution meadow at Wumeng mountainous area in Weining County of Guizhou Province. The contents of heavy metal elements were analyzed by inductively coupled plasma atomic emission spectroscopy (ICP-AES) in soil, pasture, and animal tissues, and the blood parameter was determined by automatic blood cell analyzer. The results of grazing experiments showed that the content of copper and zinc in animal tissues when Wumeng semi-fine wool sheep grazed in the copper-polluted meadow were significantly increased $(P<0.01)$, but the molybdenum content in animal tissues significantly decreased $(P<0.01)$. At the end of experiment, the $\mathrm{Hb}, \mathrm{PCV}$, and RBC of the experimental Wumeng semi-fine wool sheep were significantly lower than control group $(P<0.01)$, and mean corpuscular volume (MCV) was significantly lower than the control group $(P<0.05)$, and the wool yield and length were significantly lower than not the control group $(P<0.01)$. The results of the sulfur supplementation experiment showed that the supplementation of sodium sulfate significantly reduced the copper element content in blood and liver of Wumeng semi-fine wool sheep, the hemoglobin $(\mathrm{Hb})$, packed cell volume (PCV), and red blood cell count (RBC) in blood of the experimental Wumeng semi-fine wool sheep were significantly higher than the control group $(P<0.01)$, and the blood parameter reached the normal range at the end of the experiment. The content of copper element in blood and liver of the control group continued to increase, and the content of molybdenum in the animal tissues continued to decrease $(P<0.01)$. The $\mathrm{Hb}, \mathrm{PCV}, \mathrm{RBC}$, and MCV of the experimental Wumeng semi-fine wool sheep continued to decline, and hemolytic anemia
\end{abstract}

*e-mail: kjxyshenxy@163.com 
was seen in Wumeng semi-fine wool sheep from control group at the end of experiment. However, sulfur supplementation had no significant effect on the relevant indicators of wool quality. Conclusion: copper pollution meadow seriously affect the mineral metabolism of Wumeng semi-fine wool sheep, and we can utilize the antagonism of sulfur and copper in the food chain to achieve the goal of harmless utilization of copper pollution meadow.

Keywords: Wumeng semi-fine wool sheep, copper pollution meadow, sodium sulfate, content of heavy metal elements, mineral metabolism

\section{Introduction}

The Wumeng semi-fine wool sheep industry is the pillar industry in Wumeng mountainous area, which is the material basis for the survival and development of ethnic minorities in this area. It has the characteristics of high wool yield, good meat performance, early maturity, rough feed resistance, and strong adaptability, and it plays a key role in the development of grassland animal husbandry in Wumeng mountainous area [1-2]. The Wumeng semi-fine wool sheep has been cultivated for 44 years, it unites the efforts and sweat of several generations of scientists and technicians, and fills the gaps in the animal species without artificial cultivation in Guizhou. Wumeng semi-fine wool sheep is a breed that can produce meat and wool by crossbreeding local (mountain Tibetan coarse wool sheep) and Corriedale sheep, Sinkiang semi-fine wool sheep, and Lincoln sheep's blood, and a breeding herd of sheep has been formed with relatively good production performance and relatively stable heredity performance through grading up from 1974 to 1982 , crossing fixation from 1982 to 1990 , and expanding the herd from 1990 to 2007 [3]. Since 2007, we have further developed the cultivation of Wumeng semi-fine wool sheep on the basis of the research of the older generation of scientists and technicians, a new breed of sheep (Wumeng semifine wool sheep) with excellent production performance and stable heredity performance had been bred by 2017 , and its production performance is obviously higher than other local breeds. Wumeng semi-fine wool sheep is the main source of local people's productive life information in Wumeng mountainous area.

Heavy metal pollution refers to the pollution caused by heavy metals or their compounds to the environment [4-6]. Heavy metals have carcinogenic, teratogenic, and mutagenic effects. Heavy metals are difficult to decompose, which not only causes direct damage to organisms, but also endangers the whole ecosystem by accumulating along the food chain [4-5]. The climate of Wumeng mountainous area is warm and humid, winter is without cold, and summer is without heat. It has rich feed resources and unique natural conditions to develop grassland animal husbandry, and it is the cornucopia of mineral resources in western China. In recent years, due to the rapid development of the national economy and society, the demand for various mineral resources has been rapidly increasing, the scale of exploitation has been on the increase, mining processing enterprises mushroomed vigorously, and a large number of pollutants have been released, causing serious damage to the ecological environment. In addition, pollution also harms the animal and human health through the food chain [5-9]. Copper pollution is one of the main pollution forms in Wumeng mountainous area, and the copper content of soil and pasture in the polluted area is seriously over the standard, and the copper content in some areas is 3-5 times the normal content, accompanied by cadmium, lead, zinc, and other pollutants [9-10], it has had a serious impact on local grassland animal husbandry, especially the Wumeng semi-fine wool sheep industry. In order to find out the technology and method of harmless utilization of copper pollution for grassland and reduce the influence of copper pollution on the industry of Wumeng semifine wool sheep, we carried out research on the effect of grazing to copper pollution meadow on mineral element metabolism in the sheep.

\section{Materials and Methods}

Experimental Design

Selecting 18 Wumeng semi-fine wool 1-year-old rams randomly, their weight was $35 \pm 2.5 \mathrm{~kg}$ and clinical testing was healthy. The experimental meadow was $18 \mathrm{hm}^{2}$.

\section{Grazing Experiment}

Experimental group: $12 \mathrm{hm}^{2}$ copper-polluted grassland were selected in Mogu Town, Hezhang County of Guizhou Province, the fences were divided into two equal parts, and six Wumeng semi-fine wool sheep were grazed in each part for 60 days. Control group: $6 \mathrm{hm}^{2}$ of non-polluting grassland were selected in Liangshuigou, Weining County, Guizhou Province, and grazing 6 Wumeng semi-fine wool sheep.

\section{Sulfur Supplementation Experiment}

At the end of the grazing experiment, 12 Wumeng semi-fine wool sheep were grazed on copper pollution grassland, and were randomly divided into two groups (experimental group and control group) and 
continued to graze on the same polluted pasture. Experimental group: Wumeng semi-fine wool sheep was supplemented with sodium sulfate $\left(\mathrm{Na}_{2} \mathrm{SO}_{4}\right)$, and each sheep was supplemented with $10 \mathrm{~g}$ every day and this experiment was continued for 15 days. Control group: no processing.

\section{Sample Collection}

\section{Soil Sample Collection}

30 soil samples from $0-20 \mathrm{~cm}$ were randomly collected (10 in each experimental group, 20 in total; 10 in control group). The samples were collected in quadrats of $1 \times 1 \mathrm{~m}$, each quadrat interval was $100 \mathrm{~m}$, one sample was collected from each quadrat, and each sample was $200 \mathrm{~g}$. The sample was used to analyze the content of heavy metal elements and mark the sample points to prepare for collecting forage samples at the same location.

\section{Pasture Sample Collection}

30 sample of mixed plants were collected randomly (10 in each treatment group, 20 in total; 10 in control group). In order to reduce the influence of different pasture species on the mineral content, taking the soil sample point as the center of the circle, selecting 10 points evenly distributed $100 \mathrm{~m}$ from the center of the circle (each point was $200 \mathrm{~m}$ from each other), collecting $20 \mathrm{~g}$ grass at each point, 10 points of mixed pasture form a $200 \mathrm{~g}$ sample of forage, the pasture was collected from the ground more than $0.1 \mathrm{~cm}$ to reduce the influence of soil pollution on forage.

\section{Blood Sample Collection}

From each animal we collected $10 \mathrm{~mL}$ blood $\mathrm{f}$ rom the jugular vein. After the blood cooled, it was placed for 8 hours at a low temperature of $4-8^{\circ} \mathrm{C}$ and carried back to the laboratory for further research and analysis.

\section{Liver Biopsy Collection}

The clotting time of animal platelets was measured and the puncture point was located by ultrasound one day before surgery. On the day of surgery, the sheep was intramuscularly injected with $10 \mathrm{mg}$ vitamin $\mathrm{K}$ using codeine and phenobarbital sodium of each $0.03 \mathrm{~g}$ to anesthetize before operation. The operator used a rubber tube to connect the $20 \mathrm{~mL}$ syringe and the liver puncture needle, the syringe was sucked 3-5 $\mathrm{mL}$ with aseptic saline and we cleaned the gas in the syringe. A puncture needle was used first to prick holes in the skin, and then a liver puncture needle was used to prick holes of $0.5-1 \mathrm{~cm}$ along the upper edge of the rib. The saline in the syringe was injected into
0.5-1 $\mathrm{mL}$ to wash out the skin and subcutaneous tissue that might have existed in the liver puncture needle cavity and avoid blockage of the needle. Drawing the needle bolt to 5-6 mL scale of syringe to cause and maintain negative pressure in the needle. At the moment of the animal holding its breath, the liver tissue was punctured vertically, and the depth of puncture was about 4-6 cm. After pulling out the liver puncture needle, the needle was covered with aseptic gauze, the puncture site was pressed for a few minutes, fixed with adhesive plaster, placed with a sand bag to pressurize and tighten the abdominal belt, and the obtained liver tissue was injected into the specimen bottle to be fixed for inspection [11].

\section{Sample Processing}

The microwave digestion method that was used to heat the digestion liquid in the closed container by microwave heating and each sample was quickly dissolved in the high temperature pressurization condition. The soil, forage, and animal tissues were dried to constant weight at room temperature, the soil was screened by $200 \mathrm{mesh}$, and the soil was heated by microwave heating with nitric acid $\left(\mathrm{HNO}_{3}\right)$, perchloric acid $\left(\mathrm{HClO}_{4}\right)$ and hydrofluoric acid (HF) (5:2:5) mixture to dissolve the sample. The forage and animal tissues were heated by microwave heating with nitric acid and perchloric acid (4:1) mixture to dissolve the sample [12].

\section{Analytical Testing}

\section{Detection of Heavy Metal Element}

The contents of heavy metals in soils, pastures, and animal tissues were analyzed by inductively coupled plasma atomic emission spectroscopy (ICP-AES) ${ }^{(12)}$. The instrument used was an HK9600 inductively coupled plasma atomic emission spectrometer (Huaketiancheng Co., Ltd, China). The element types analyzed were $\mathrm{Mn}, \mathrm{Zn}, \mathrm{Co}, \mathrm{Cu}, \mathrm{Fe}$, $\mathrm{P}$, and Mo.

\section{Detecting Blood Parameters}

We used an automatic blood cell analyzer for animals to detect hemoglobin ( $\mathrm{Hb})$, white blood cell count (WBC), red blood cell count (RBC), packed cell volume (PCV), mean corpuscular volume (MCV), mean corpuscular hemoglobin $(\mathrm{MCH})$, and mean corpuscular hemoglobin concentration (MCHC) [2].

\section{Data Analysis}

Using SPSS 22.0 to dispose of and analyze research data, the data were analyzed by using independent samples of t-test to evaluate the significant differences among treatments. 
Table 1. Mineral content in soil and forage of copper pollution meadow (ppm).

\begin{tabular}{|c|c|c|c|c|}
\hline \multirow{2}{*}{ Element } & \multicolumn{2}{|c|}{ Experimental group } & \multicolumn{2}{c|}{ Control group } \\
\cline { 2 - 5 } & Soil & Forage & Soil & Forage \\
\hline $\mathrm{Mn}$ & $125 \pm 24.5$ & $66.8 \pm 15.6$ & $127 \pm 37.2$ & $67.9 \pm 17.1$ \\
\hline $\mathrm{Zn}$ & $37.0 \pm 6.27^{*}$ & $8.19 \pm 2.29^{*}$ & $34.9 \pm 6.31^{*}$ & $7.73 \pm 2.21^{*}$ \\
\hline $\mathrm{Co}$ & $6.38 \pm 1.22$ & $4.38 \pm 1.36$ & $6.50 \pm 1.67$ & $4.12 \pm 1.31$ \\
\hline $\mathrm{Cu}$ & $76.1 \pm 19.8^{* *}$ & $17.2 \pm 7.43^{* *}$ & $15.1 \pm 2.41^{* *}$ & $6.78 \pm 1.31^{* *}$ \\
\hline $\mathrm{Fe}$ & $3721 \pm 126$ & $369 \pm 67.3$ & $3823 \pm 135$ & $353 \pm 76.7$ \\
\hline $\mathrm{P}$ & $53.8 \pm 6.97$ & $426 \pm 58.7$ & $67.8 \pm 7.31$ & $466 \pm 56.9$ \\
\hline $\mathrm{Mo}$ & $2.74 \pm 0.57$ & $2.23 \pm 0.31$ & $2.86 \pm 0.55$ & $2.27 \pm 0.23$ \\
\hline $\mathrm{Se}$ & $0.13 \pm 0.02$ & $0.13 \pm 0.05$ & $0.13 \pm 0.02$ & $0.12 \pm 0.03$ \\
\hline
\end{tabular}

${ }^{* *}:$ indicate highly significant differences at $P<0.01$ level.

*:indicate significant differences at $P<0.05$ level, the same below.

\section{Results}

\section{Grazing Experiment of Copper Pollution Meadow}

Grazing the copper pollution grassland had a remarkable effect on the growth rate of the sheep $(\mathrm{P}<0.01)$. During the whole trial period, the average weight gain in the experimental group was $9.78 \pm 1.21$ $\mathrm{kg}$ and in the control group $13.65 \pm 2.12 \mathrm{~kg}$. Grazing the polluted grassland had a remarkable effect on the copper content of wool $(\mathrm{P}<0.01)$, with average copper content in the experimental group being $8.79 \pm 0.72 \mathrm{ppm}$ and in the control group $5.51 \pm 1.32 \mathrm{ppm}$.

\section{Mineral Element Content of Soil and Forage in a Copper-Polluted Meadow}

Copper content of soils and forage in the copperpolluted meadow was significantly higher than the control group $(\mathrm{P}<0.01)$. Zinc content was significantly higher than the control group $(\mathrm{P}<0.05)$. Other elements
Table 3. Liver mineral content of animals (ppm).

\begin{tabular}{|c|c|c|}
\hline Element & Experimental group & Control group \\
\hline $\mathrm{Mn}$ & $4.31 \pm 1.32$ & $4.39 \pm 1.27$ \\
\hline $\mathrm{Zn}$ & $63.7 \pm 12.6$ & $53.9 \pm 12.8$ \\
\hline $\mathrm{Co}$ & $6.95 \pm 1.27$ & $6.93 \pm 1.17$ \\
\hline $\mathrm{Cu}$ & $577 \pm 34.7^{* *}$ & $137 \pm 12.7^{* *}$ \\
\hline $\mathrm{Fe}$ & $328 \pm 37.7^{* *}$ & $338 \pm 37.9^{* *}$ \\
\hline $\mathrm{P}$ & $633 \pm 39.8$ & $633 \pm 39.7$ \\
\hline $\mathrm{Mo}$ & $1.37 \pm 0.17^{* *}$ & $2.38 \pm 0.67^{* *}$ \\
\hline $\mathrm{Se}$ & $0.11 \pm 0.03$ & $0.11 \pm 0.02$ \\
\hline
\end{tabular}

had no significant difference. In general, the highest permitted limits for copper and zinc do not exceed $35 \mathrm{ppm}$ and $100 \mathrm{ppm}$ in soils, and the highest permitted limits for copper and zinc do not exceed $10 \mathrm{ppm}$ and $20 \mathrm{ppm}$ in feeds (Table 1).

\section{Effect of Copper Pollution on the Blood Mineral Content of Animals}

The copper and zinc content of blood in the copperpolluted meadow was significantly higher than the control group $(\mathrm{P}<0.01)$, molybdenum and iron content was significantly lower than the control group $(\mathrm{P}<0.01)$, and there were no significant differences between other elements (Table 2)

\section{Effect of Copper Pollution on the Liver Mineral Content of Animals}

The copper and zinc content of liver in the copperpolluted meadow was significantly higher than the control group $(\mathrm{P}<0.01)$, molybdenum and iron content was significantly lower than the control group $(\mathrm{P}<0.01)$, and there were no significant differences between other elements (Table 3).

Table 4. Effects of copper pollution on the blood parameters of animals.

\begin{tabular}{|c|c|c|}
\hline Blood parameter & Experimental group & Control group \\
\hline $\mathrm{Hb}(\mathrm{g} / \mathrm{L})$ & $82.6 \pm 13.7^{* *}$ & $117.2 \pm 12.7^{* *}$ \\
\hline $\mathrm{RBC}\left(10^{12} / \mathrm{L}\right)$ & $5.89 \pm 0.23^{* *}$ & $7.93 \pm 0.24^{* *}$ \\
\hline $\mathrm{PCV}(\%)$ & $31.1 \pm 3.92^{* *}$ & $45.6 \pm 3.52^{* *}$ \\
\hline $\mathrm{MCV}(\mathrm{fl})$ & $52.8 \pm 4.73^{*}$ & $56.8 \pm 5.93^{*}$ \\
\hline $\mathrm{MCH}(\mathrm{pg})$ & $14.0 \pm 2.36$ & $14.8 \pm 2.97$ \\
\hline $\mathrm{MCHC}(\%)$ & $26.6 \pm 4.27$ & $25.7 \pm 4.11$ \\
\hline $\mathrm{WBC}\left(10^{9} / \mathrm{L}\right)$ & $9.65 \pm 0.79$ & $9.37 \pm 0.62$ \\
\hline
\end{tabular}

Table 2. Blood mineral content of animals (ppm).

\begin{tabular}{|c|c|c|}
\hline Element & Experimental group & Control group \\
\hline $\mathrm{Mn}$ & $0.73 \pm 0.18$ & $0.75 \pm 0.13$ \\
\hline $\mathrm{Zn}$ & $3.73 \pm 0.13$ & $2.13 \pm 0.11$ \\
\hline $\mathrm{Co}$ & $0.69 \pm 0.12$ & $0.71 \pm 0.21$ \\
\hline $\mathrm{Cu}$ & $17.5 \pm 0.87^{* *}$ & $1.79 \pm 0.31^{* *}$ \\
\hline $\mathrm{Fe}$ & $219 \pm 27.9^{* *}$ & $215 \pm 23.8^{* *}$ \\
\hline $\mathrm{P}$ & $243 \pm 23.7$ & $241 \pm 21.7$ \\
\hline $\mathrm{Mo}$ & $0.11 \pm 0.02^{* *}$ & $0.19 \pm 0.03^{* *}$ \\
\hline $\mathrm{Se}$ & $0.13 \pm 0.06$ & $0.12 \pm 0.05$ \\
\hline
\end{tabular}


Table 5. Effect of copper pollution meadow on the quality and yield of wool.

\begin{tabular}{|c|c|c|}
\hline Wool & $\begin{array}{c}\text { Experimental } \\
\text { group }\end{array}$ & $\begin{array}{c}\text { Control } \\
\text { group }\end{array}$ \\
\hline Yield $(\mathrm{kg})$ & $2.8 .6 \pm 0.27 * *$ & $3.72 \pm 0.28 * *$ \\
\hline Net wool rate $(\%)$ & $56.9 \pm 8.23$ & $57.93 \pm 9.24$ \\
\hline Fineness $(\mu \mathrm{m})$ & $27.1 \pm 3.92$ & $26.6 \pm 3.52$ \\
\hline Length $(\mathrm{cm})$ & $14.8 \pm 1.73^{* * *}$ & $15.18 \pm 2.13^{* *}$ \\
\hline
\end{tabular}

\section{Effect of Copper Pollution on the Blood Parameters of Animals}

$\mathrm{Hb}, \mathrm{PCV}$, and $\mathrm{RBC}$ of sheep in the experimental group were significantly lower than the control group $(\mathrm{P}<0.01)$. MCV was significantly lower than the control group $(\mathrm{P}<0.05)$, and there were no significant differences in other indicators (Table 4).

\section{Effect of Copper-Polluted Meadow on Wool Quality and Yield}

The yield and length of wool in the experimental group were significantly lower than the control group $(\mathrm{P}<0.01)$. There was no significant effect on the net wool rate and fineness (Table 5).

\section{Supplementary Mineral Experiments in Animals}

Sulfur supplementation had no significant effect on yield, clean wool rate, fineness, length, and growth rate of wool during the whole trial period. The average weight gain of sheep in the experimental group was $3.78 \pm 0.13 \mathrm{~kg}$ and that in the control group was $3.97 \pm 0.12 \mathrm{~kg}$. Grazing the copper-polluted grassland had no significant effect on the copper content of wool, and the average copper content of sheep in

Table 6. Effect of sulfur supplementation on the blood mineral content of animals (ppm).

\begin{tabular}{|c|c|c|c|c|}
\hline \multirow{2}{*}{ Elements } & \multicolumn{2}{|c|}{ Experimental group } & \multicolumn{2}{c|}{ Control group } \\
\cline { 2 - 5 } & Start & Finish & Start & Finish \\
\hline $\mathrm{Mn}$ & $0.71 \pm 0.17$ & $0.72 \pm 0.12$ & $0.70 \pm 0.13$ & $0.73 \pm 0.18$ \\
\hline $\mathrm{Zn}$ & $3.33 \pm 0.19$ & $3.13 \pm 0.13$ & $3.51 \pm 0.15$ & $3.73 \pm 0.13$ \\
\hline $\mathrm{Co}$ & $0.67 \pm 0.13$ & $0.70 \pm 0.17$ & $0.67 \pm 0.14$ & $0.69 \pm 0.12$ \\
\hline $\mathrm{Cu}$ & $13.1 \pm 1.82^{* *}$ & $1.91 \pm 0.21^{* *}$ & $13.3 \pm 1.57$ & $17.5 \pm 2.71$ \\
\hline $\mathrm{Fe}$ & $217 \pm 17.9$ & $215 \pm 23.8$ & $218 \pm 21.9$ & $219 \pm 27.9$ \\
\hline $\mathrm{P}$ & $241 \pm 22.7$ & $242 \pm 21.7$ & $233 \pm 23.1$ & $243 \pm 23.7$ \\
\hline $\mathrm{Mo}$ & $0.11 \pm 0.02^{* *}$ & $0.03 \pm 0.04^{* *}$ & $0.11 \pm 0.01$ & $0.05 \pm 0.02$ \\
\hline $\mathrm{Se}$ & $0.13 \pm 0.02$ & $0.12 \pm 0.05$ & $0.13 \pm 0.06$ & $0.12 \pm 0.05$ \\
\hline
\end{tabular}

the experimental group was $8.79 \pm 0.72 \mathrm{ppm}$ and that in the control group was $8.58 \pm 0.18 \mathrm{ppm}$.

\section{Effect of Sulfur Supplementation on the Blood Mineral Content of Animals}

Compared with the beginning of the experiment, the copper content in the experimental group decreased significantly $(\mathrm{P}<0.01)$ and was significantly lower than the control group $(\mathrm{P}<0.01)$. Molybdenum content in the experimental group decreased significantly $(\mathrm{P}<0.01)$, but the difference with the control group was not obvious at the end of the experiment. The copper content in the control group continued to increase significantly $(\mathrm{P}<0.01)$ and it was significantly higher than the experimental group $(\mathrm{P}<0.01)$, but the other elements had no significant difference (Table 6).

\section{Effect of Sulfur Supplementation on the Blood Parameters of Animals}

At the end of the experiment, $\mathrm{Hb}, \mathrm{PCV}, \mathrm{RBC}$, and $\mathrm{MCV}$ of sheep in the experimental group were significantly higher than the control group $(\mathrm{P}<0.01)$, and it was also significantly higher than the beginning of the experiment $(\mathrm{P}<0.01)$. The other indicators had no significant difference. The $\mathrm{Hb}, \mathrm{PCV}, \mathrm{RBC}$, and $\mathrm{MCV}$ of Sheep in the control group were significantly higher than the beginning of the experiment $(\mathrm{P}<0.01)$, and hemolytic anemia appeared in the control group at the end of the experiment (Table 7).

\section{Effect of Sulfur Supplementation on the Liver Mineral Content of Animals}

At the end of the sulfur supplementation experiment, the copper content of liver in the experimental group basically reached the normal range, which was significantly lower than the beginning of the experiment $(\mathrm{P}<0.01)$, and it was also significantly lower than the control group $(\mathrm{P}<0.01)$. Molybdenum content of liver was significantly lower than at the beginning of the experiment $(\mathrm{P}<0.01)$. At the end of the experiment, the copper content of liver in the control group was significantly higher than at the beginning of the experiment $(\mathrm{P}<0.01)$, molybdenum content of liver was significantly lower than at the beginning of the experiment $(\mathrm{P}<0.01)$, and the other elements had no significant difference (Table 8).

\section{Discussion}

Heavy metal pollution has become a focus of attention all over the world. The research on methods and mechanisms of heavy metal pollution control is a research priority of environmental science [1315], and making full use of the interaction between elements to reduce the impact of heavy metal pollution 
Table 7. Effect of mineral element supplementation on the blood parameters of animals.

\begin{tabular}{|c|c|c|c|c|}
\hline \multirow{2}{*}{ Blood parameter } & \multicolumn{2}{|c|}{ Experimental group } & \multicolumn{2}{c|}{ Control group } \\
\cline { 2 - 5 } & Start & Finish & Start & $62.6 \pm 10.1$ \\
\hline $\mathrm{Hb}(\mathrm{g} / \mathrm{L})$ & $72.1 \pm 11.3^{* *}$ & $113 \pm 12.5^{* *}$ & $72.6 \pm 11.7$ & $3.89 \pm 0.81$ \\
\hline $\mathrm{RBC}\left(10^{12} / \mathrm{L}\right)$ & $4.79 \pm 0.27^{* *}$ & $7.74 \pm 0.21^{* *}$ & $4.89 \pm 0.21$ & $25.1 \pm 3.17$ \\
\hline $\mathrm{PCV}(\%)$ & $31.1 \pm 3.91^{* *}$ & $45.7 \pm 3.56^{* *}$ & $30.1 \pm 3.93$ & $47.8 \pm 3.19$ \\
\hline $\mathrm{MCV}(\mathrm{fl})$ & $51.3 \pm 4.72^{*}$ & $56.2 \pm 3.27^{*}$ & $51.8 \pm 4.75$ & $14.5 \pm 2.37$ \\
\hline $\mathrm{MCH}(\mathrm{pg})$ & $14.1 \pm 2.37$ & $14.1 \pm 2.66$ & $14.0 \pm 2.35$ & $27.1 \pm 3.21$ \\
\hline $\mathrm{MCHC}(\%)$ & $26.7 \pm 2.21$ & $26.9 \pm 3.72$ & $26.1 \pm 4.21$ & $9.71 \pm 0.77$ \\
\hline $\mathrm{WBC}\left(10^{9} / \mathrm{L}\right)$ & $9.65 \pm 0.71$ & $9.37 \pm 0.69$ & $9.63 \pm 0.73$ & \\
\hline
\end{tabular}

on animals is one of the effective control measures to control heavy metal pollution [16-20]. Grazing a copper-polluted meadow significantly increased the copper content of blood and liver, and hemolytic anemia was seen in sheep, which seriously affected the growth and development of the animals. In the sulfur supplementation experiment, the copper content of blood and liver was effectively reduced by the interaction of sulfur and copper, but there was no significant effect on growth and development of animals. The author thinks that the sulfur supplementation experiment was only 15 days, and the animal was still in the recovery of the poisoning state. If a long-term experiment were to be carried out, the growth of the experimental animal would be improved effectively, but further research is urgently needed.

\section{Effect of Grazing a Copper-Polluted Meadow on Liver Mineral Content of Animals}

Sheep are the main livestock in the Wumeng Mountainous area, where heavy metal pollution is widespread [20-22]. The heavy metals in animal tissues are mainly from soil and pasture, and the main causes

Table 8. Effect of sulfur supplementation on the liver mineral content of animals (ppm).

\begin{tabular}{|c|c|c|c|c|}
\hline \multirow{2}{*}{ Elements } & \multicolumn{2}{|c|}{ Experimental group } & \multicolumn{2}{c|}{ Control group } \\
\cline { 2 - 5 } & Start & Finish & Start & Finish \\
\hline $\mathrm{Mn}$ & $4.31 \pm 1.32$ & $4.29 \pm 1.87$ & $4.32 \pm 1.31$ & $4.21 \pm 1.31$ \\
\hline $\mathrm{Zn}$ & $63.7 \pm 12.6$ & $66.7 \pm 11.3$ & $63.1 \pm 11.6$ & $61.7 \pm 12.2$ \\
\hline $\mathrm{Co}$ & $6.95 \pm 1.27$ & $7.12 \pm 1.37$ & $6.93 \pm 1.25$ & $6.93 \pm 1.23$ \\
\hline $\mathrm{Cu}$ & $577 \pm 34.7^{* *}$ & $135 \pm 22.7^{* *}$ & $576 \pm 31.8$ & $777 \pm 71.7$ \\
\hline $\mathrm{Fe}$ & $328 \pm 37.7$ & $319 \pm 36.8$ & $325 \pm 37.1$ & $318 \pm 32.7$ \\
\hline $\mathrm{P}$ & $633 \pm 39.8$ & $619 \pm 31.2$ & $631 \pm 37.8$ & $637 \pm 37.6$ \\
\hline $\mathrm{Mo}$ & $1.36 \pm 0.15^{* *}$ & $1.00 \pm 0.13^{* *}$ & $1.37 \pm 0.16$ & $1.31 \pm 0.17$ \\
\hline $\mathrm{Se}$ & $0.11 \pm 0.03$ & $0.12 \pm 0.02$ & $0.13 \pm 0.03$ & $0.12 \pm 0.03$ \\
\hline
\end{tabular}

of heavy metal poisoning or deficiency in animals include two aspects: one is that the heavy metal content of forage is too high, causing the heavy metal content in animal tissues to exceed the standard; the second is the excess or lack of some elements caused by the interaction between elements [21-23]. In our study, the copper content of soil and pasture in copper-polluted grassland was significantly higher than the control group $(\mathrm{P}<0.01)$, and it was also significantly higher than the normal range. Copper pollution caused serious damage to the grazing animals through the food chain, and caused the copper content of blood and liver to be significantly higher than the control group. The copper content of liver in the experimental group was about 4.2 times that of the control group. The liver is the main organ for storing copper in animals, and high levels of copper can damage liver nuclear, mitochondria, and subcellular structures of the liver serous, thus it caused abnormal liver function [24-25].

\section{Effect of Grazing Copper-Polluted Meadow on Blood Parameters of Animals}

At the end of the experiment, $\mathrm{Hb}, \mathrm{PCV}$, and $\mathrm{RBC}$ of the grazing animals in copper-polluted grassland were significantly lower than the control group $(\mathrm{P}<0.01), \mathrm{MCV}$ of the grazing animal in copper-polluted grassland was significantly lower than the control group $(\mathrm{P}<0.05)$, and hemolytic anemia appeared. When the copper content of blood increases, the liver can take a large amount of copper from the blood, and if the copper content exceeds the tolerance limit, the activities of various enzymes can be inhibited, which can make liver cell denaturation necrotic and cause copper excretion dysfunction. When the copper concentration of liver is too high, it has a large number of copper released into the blood, and then enters the red blood cells, and the intracellular copper concentration continues to rise so that the concentration of glutathione in red blood cells is reduced, erythrocyte fragility is increased, and tube hemolysis appears. Renal copper concentration is increased, the renal tubules are blocked by hemoglobin, and the renal unit is necrosis, eventually leading to 
renal failure and hematuria [26-31]. If the liver cells are regenerated and sufficient to absorb the copper released from the dead hepatocyte, the clinical manifestation does not appear to be symptomatic and hemolysis even if the intrahepatic copper content is high; if liver cells cannot regenerate effectively, it will prompt the copper to enter the blood rapidly, and the level of plasma copper is raised, a large amount of erythrocytes destroyed and hemolysis appears, which accelerates hepatic necrosis and releases more copper into the bloodstream. In turn, this situation starts all over again, which may cause hemolytic anemia [24, 30, 32].

\section{Effect of Grazing Copper-Polluted Meadow on the Quality and Yield of Wool}

The yield and length of wool in the experimental group were significantly lower than the control group $(\mathrm{P}<0.01)$. Sulfur is the most important nutrition for animals and is a major component of protein (31). Wool includes the scales, the cortex, and the medullary layer, and their main component is protein, so the growth of wool requires a lot of sulfur. In our study, the copper content of soil and pasture was significantly higher than the normal requirement. In the ruminant rumen, the copper content of blood and liver can significantly affect the absorption and utilization of sulfur, and fodder with high copper will cause animal sulfur deficiency, which will be an inevitable result affecting wool yield $[1,2]$.

\section{Effects of Sulfur Supplementation on Animal Tissue and Blood Parameters}

Both essential and nonessential elements can be toxic to tissues and organs when they accumulate in large quantities in animals [29, 33, 34]. In order to avoid their toxic effects, animals have joint regulation mechanisms such as inhibition of intake, isolation, and enhanced discharge. In addition, they can prevent and reduce toxicity by regulating the metal-binding protein and gradually achieving detoxification $[25,35$, 36]. However, the interaction between heavy metals is also a major measure for reducing the impact of heavy metals on the body, and there is a complex relationship between sulfur, molybdenum, and copper, with sulfur and molybdenum forming copper molybdate to enclose absorption sites and reduce copper absorption in the intestinal tract. The compound of copper-molybdenumsulfur protein is more stable in the blood and the copper is not readily available for tissues [37-42]. In the liver, sulfur molybdate can directly peel the copper from the metal sulfur protein, the stripped copper enters blood and bile with small molecular substances, and then the metal sulfur protein transfers and supplements the copper to the other proteins. The copper is peeled off again and this cycle starts all over again, which may cause copper storage in the animal, and the copper content of blood and the toxicity of copper pollution is eventually reduced. In our study, the reduction of copper in liver and blood was achieved by sodium sulfate supplementation, the blood parameter of animal returned to normal at the end of the supplementation experiment.

\section{Conclusion}

Copper is an essential nutrient for animals and plants in a certain range, but the copper content of environment is too high which can produce an environmental copperpolluted, the copper content of environment is too low which can cause copper deficiency of environment, there is still a large amount of natural grassland and cultivated land lacking of copper in our country [43], and there are also many people suffering from anemia caused by copper deficiency [44]. Through the interference of sulfur elements and grazing regulation, the high copper mutton can be produced in the condition of guaranteeing the health in sheep to use as an important copper supplement for the copper deficiency population, the excreted copper can be converted into functional organic fertilizer through organic processing techniques to use as an important copper source for natural grassland and farmland of copper deficiency. However, our research has just begun, deep research and exploration need to be further carried out to achieve the research goal.

\section{Acknowledgements}

The acknowledgements are for the supports by Project of National Key Research and Development Program of China in the 13th Five-year Plan: Ecological industry model and integrated technology and demonstration for the rocky desertification control of the karst plateau gorge (2016YFC0502601, 2016YFC0502607); The Program of National Natural Science Foundation of China (No. 41671041); The Project of Innovation Program for Postgraduate Education of Guizhou Province: Xiong Kangning's studio of postgraduate supervisors for the karst environment of Guizhou Province (QIANJIAOYANHE GZS ZI [2016]04); The Key Project of Science and Technology Program of Guizhou Province: Key technology and demonstration for the State Engineering Technology Institute for Karst Desertfication Control "(Qiankehe Zhongdazhuanxiang Zi [2014] 6007); The Project of Science and Technology Program of Guizhou Province: Construction for the Provincial Engineering Technology Institute for Karst Desertfication Control (Qiankeheshe G zi [2012] 4008)

\section{Conflict of Interest}

The authors declare no conflict of interest. 


\section{References}

1. SHEN X.Y., ZHANG M., XIONG K.N. Effected of molybdenum on sulfur metabolism in guizhou sem-fine wool sheep in south west China karst mountain area. Journal of Animals and Veterinary Advance 13 (17), 1027, 2014.

2. SHEN X.Y. Studies on Wool-Eating Ailment in guizhou semi-fine wool sheep. Agricultural Sciences in China $\mathbf{1 0}$ (10), 161, 2011.

3. LI L.J., SHEN X.Y. Development progress and breeding status of guizhou semi-fine-wool sheep. Guizhou Agricultural Science 38 (11), 182, 2010.

4. ARTHINGTON J.D., RECHCIGL J.E., YOST G.P., MCDOWELL L.R., FANING M.D. Effect of ammonium sulfate fertilization on bahiagrass quality and copper metabolism in grazing beef cattle. Journal of Animal Science 80, 2507, 2002.

5. BESNARD E., CHENU C., ROBERT M. Influence of organic amendments on copper distribution among particle-size and density fractions in champagne vineyard soils. Environmental Pollution 112, 329, 2011.

6. BRUN L.A., MAILLET J., HINSINGER P., PÉPIN M. Evaluation of copper availability to plants in copper contaminated vineyard soils. Environmental Pollution 111, 293, 2011.

7. BRUN L.A., MAILLET J., RICHARTE J., HERRMANN P., REMY J.C. Relationships between extractable copper, soil properties and copper uptake by wild plants in vineyard soils. Environmental Pollution 102, 151, 1988.

8. CAO Z.H., HU Z.Y., WONG M.H. Copper contamination in paddy soils irrigated with wastewater, special issue of Environmental contamination, toxicology and health. Chemosphere 41, 3, 2004.

9. SONG Y.L., ZENG Y., YANG H.Q. Spatiotemporal distribution potential ecological risk assessment of heavy metals in the sediments of lake Caohai Guizhou China, Chinese Journal of Ecology 35 (7), 1849, 2016.

10. WU Z.Q., GU S.Y., LI H.Y., HONG W.U. Research on the heavy metal contamination and bioavailability of contaminated soils in $\mathrm{Pb}-\mathrm{Zn}$ mining areas of northwestern Guizhou province. Safety and Environmental Engineering 16 (3), 1, 2009.

11. ARTHINGTON J.D., CORAH L.R. Liver biopsy procedures of animals; part II (Video, AI 8134). extension $\mathrm{TV}$, dept. of communications, cooperative extension service, Kansas State Univ, Manhattan 1995.

12. FRANZBLAU A., ROSENSTOCK L., EATON D.L. Use of inductively coupled plasma-atomic emission spectroscopy (ICP-AES) in screening for trace metal exposures in an industrial population. Environmental Research 46 (1), 15, 1998.

13. CHEN X., LU X., LI L.Y., GAO Y. Spatial distribution and contamination assessment of heavy metals in urban topsoil from inside the xi'an second ringroad, NW China. Environmental Earth Science 68 (7), 1979, 2013.

14. GASIOREK M., KOWALSKA J., MAZUREK, R. Comprehensive assessment of heavy metal pollution in topsoil of historical urban park on an example of the planty park in krakow (Poland). Chemosphere 179, 148, 2017.

15. GRACE N.D., ROUNCE J.R., LEE J. Effect of soil ingestion on the storage of Se, Vitamin $\mathrm{B} 12, \mathrm{Cu}, \mathrm{Cd}, \mathrm{Fe}$, $\mathrm{Mn}$, and $\mathrm{Zn}$ in the liver of sheep. New Zealand Journal of Agricultural Research 39, 325, 1996.
16. HE Y., MA W., LI Y., LIU J., JING W., WANG L. Expression of metallothionein of freshwater crab (sinopotamon henanense) in escherichia coli enhances tolerance and accumulation of zinc, copper and cadmium. Ecotoxicology 23 (1), 56, 2014.

17. HU B., CHEN S., HU J., XIA F., XU J., LI Y. Application of portable xrf and vnir sensors for rapid assessment of soil heavy metal pollution. Plos One 12 (2), e0172438, 2017.

18. LATIF R., MALEK M., MIRONSEF H. Cadmium and lead accumulation in three endogeic earthworm species. Bulletin of Environmental Contamination and Toxicology 90 (4), 456, 2013.

19. LI K., ZHU J.Z. Effect of boron and molybdenum on the seed yield alfalfa. Pratacultural Science 26 (1), 61, 2009.

20. LUO J.C., ZHOU M., WANG Z.L., ZHANG Y. Fluxion and regulation of selenium in soil, plants, and animals in grassland grazing system. Pratacultural Science 34 (4), 869, 2017.

21. LI Z., MA Z., VANDER K.T.J., YUAN Z., HUANG L. A review of soil heavy metal pollution from mines in china: pollution and health risk assessment. Science of the Total Environment s468, 843, 2014.

22. MAO H., WANG D.H., YANG W.X. The involvement of metallothionein in the development of aquatic invertebrate. Aquatic Toxicology 110 (11), 208, 2012.

23. MEIERS S., CURAQUEO G., KHAN N., BOLAN N., RILLING J., VIDALC. Effects of biochar on copper immobilization and soil microbial communities in a metalcontaminated soil. Journal of Soils \& Sediments 17 (5), 1237, 2017.

24. YUAN R. Effect of Fertilizer Treatment to Copperpolluted Meadow on Copper Metabolism in Guizhou Semi- Fine Wool Sheep. Lanzhou University 1, 2012.

25. ZOU X.M., LI Z.M., YANG S.B. Epairment effect of Metallothionein on oxidative damage in mice liver infected with chromium. Studies of Trace Elements and Health $\mathbf{3 0}$ (6), 1, 2012.

26. MEIERS S., CURAQUEO G., KHAN N., BOLAN N., CEA M., EUGENIA G.M. Chicken-manure-derived biochar reduced bioavailability of copper in a contaminated soil. Journal of Soils \& Sediments 17 (3), 741, 2017.

27. PAUL-PONT I., GONZALEZ P., MONTERO N., MONTAUDOUIN X.D., BAUDRIMONT M. Cloning, characterization and gene expression of a metallothionein isoform in the edible cockle cerastoderma edule, after cadmium or mercury exposure. Ecotoxicology \& Environmental Safety 75 (1), 119, 2012.

28. PETTERS P.W. Chelant extraction of heavy metals from contaminate soils. Journal of Hazardous Materials 66, 151, 1999.

29. SCHRAMEL O., MiCHALKE B., KETTRUP A. Study of the copper distribution in contaminated soils of hop fields by single and sequential extraction procedures. The Science of the Total Environment 263, 11, 2000.

30. SHEN X.Y., DU G.Z. Studies of a naturally occurring molybdenum-induced copper deficiency in the yak. The Veterinary Journal. 171 (2), 352, 2006

31. SHEN, X.Y., JIANG H.M., YUAN R., JIA Z.H. Effect of nitrogen fertilizer source on mineral element content of forage and in the blood of grazing guizhou semi-fine sheep. Acta Prataculturae Sinica 21 (3), 275, 2012.

32. SHEN, X.Y., LI X., ZHANG R.D. Studies on unsteady gait diseas6e of the Tibetan gazelles. The Journal of Wildlife Disease 46 (2), 560, 2010. 
33. XIE Y., CHEN T.B., LEI M. Spatial distribution of soil heavy metal pollution estimated by different interpolation methods: accuracy and uncertainty analysis. Chemosphere 82 (3), 468, 2011.

34. XIONG W., DING X., ZHANG Y., SUN Y. Ecotoxicological effects of a veterinary food additive, copper sulphate, on antioxidant enzymes and mrna expression in earthworms. Environmental Toxicology \& Pharmacology 37 (1), 134, 2014.

35. ZHAO F.J., MA Y., ZHU Y.G., TANG Z., MCGRATH S.P. Soil contamination in china: current status and mitigation strategies. Environmental Science \& Technology 49(2), 750, 2015.

36. CHEN L. Consideration on the applicable standards for remediation of heavy metal pollution. Environment and Sustainable Development 42 (2), 71, 2017.

37. LI M., ZENG D.H. Research progress on phytoremediation of heavy metal pollution. Guizhou Agricultural Science 35 (3), 135, 2007.

38. LI Z.Q., WANG B.B., NIE J.H. Effects of copper on earthworm in body weight and its copper accumulating characteristics. Acta Ecologica Sinica 29 (3), 1408, 2009.
39. SHEN, X.Y. Forage strategy of Przewalski's gazelle under selenium stress. Acta Ecologica Sinica 29 (6), 2775, 2009.

40. WANG T., CHANG G.F. Present situation and remediation technology research progress for heavy metal contaminated soil. Inner Mongolia Environmental Sciences 29 (1), 191, 2017.

41. ZHAO M. Present situation, cause, harm and remediation of heavy metal pollution in soil. Resources Economization \& Environment Protection 11 (4), 181, 2016.

42. ZHANG H.J., LIU Y.G., WANG Y. Arsenic speciation analysis of sediment in the ecological restoration area of heavy metal polluted river. Environmental Pollution and Control 39 (4), 392, 2007.

43. SHEN X.Y., DU G.Z., CHEN Y.M., FAN B.L. Copper deficiency in yaks on pasture in western china. The Canadian Veterinary Journal 47 (9), 902, 2006.

44. GIOVANNONI G. Human swayback disease: expanding the spectrum of disease associated with abnormal copper metabolism. Journal of Neurology 248 (8), 707, 2001. 
